\title{
A COMPARATIVE STUDY ON AHP AND DEA
}

\author{
Raoru Tone \\ Graduate School of Pollcy Sclence, Saltama University \\ Urawa, Saltama 338 , Japan
}

\begin{abstract}
Both Analytic Hierarchy Process (AHP) and Data Envelopment Analysis (DEA), aim at making decislons under multiple criteria environments. AHP uses pairwise comparisons and elgenvector welghtings, whereas DEA does I inear fractional programmings. In this paper, we will point out some structural stmilarities among them, by comparing the benefit/cost analysis by AHP and DEA. Also, we will discuss on the fixed vo. variable welghts in multiple criteria decision making.
\end{abstract}

\section{A GLIhPSB at DATA ENYELOPMENT ANALYSIS}

DEA has been developed by A.Charnes, W.W. Cooper et al. ([1],[2],[3],[4]) since 1978. DEA estimates relative efflciencies of decision making unitg (DMUs) who have common factors of inputs and outputs. Let the multiple inputs and outputs to a DMU, $(j=1, \ldots, n)$ be $\left\{x_{1}: 1=1, \ldots\right.$ m $)$ and $\{y,: r=1, \ldots, 8\}$ tespectively. We assume that we have ( $\left.x_{1}\right)$ and $\left(y_{y}\right)$ in the form of observations or in the fotw of theofetically prescribed values and their values are positive. Also, we assume that the data are normalized so that they satigfy

and

$$
\sum_{j=1}^{n} x_{1 j}=1 \quad(1=1, \ldots, m)
$$

$$
\sum_{j=1}^{n} y_{r j}=1 \quad(r=1, \ldots, s) \text {. }
$$

This assupption 18 latd for comparative study's sake and does not Influence any essential features of DEA. From the efficiency's point of view, a DMU with blg outputs relative to small initg are preferable. We define the relative efficlency of a DMU $j_{0}$ by solving the following linear fractional programming:

$\left[F P\left(1_{0}\right)\right]$

$$
\max _{u, v} h_{j_{0}}=\left(\sum_{r=1}^{8} u_{r} y_{r j_{0}}\right) /\left(\sum_{i=1}^{m} v_{1} x_{1 j_{0}}\right)
$$

subject to 


$$
\begin{aligned}
& \left(\sum_{r=1}^{8} u_{r} y_{r j}\right) /\left(\sum_{1=1} v_{1} x_{1 j}\right) \leq 1 \quad(J=1, \ldots, n) \\
& u_{r}>0 \quad(r=1, \ldots, s) \\
& v_{1}>0 \quad(1=1, \ldots, s) .
\end{aligned}
$$

and

und and $v_{1}$ are the welghts to the $r-t h$ output $y_{r}$ and to the $1-t^{1}$ input $x_{1}$, regpectlvely. We define the efficiency of a DMU to be the fatlo of velghted sun of output values vs. welghted sum of input values. [FP(J)] maximizes the ratio assoclated with the DMU $j_{0}$, keeping the ratios of every DMUs, including $D M U J_{0}$, not grefter than 1 . Let the optimal solution to [FP(j)] be $u^{*}, v^{*}$ and $h^{*}{ }_{j}$.
These values vary from one DMU to ahother.

[Definftion 1$]$

If $h^{*} j_{0}$ then the DMU $j_{0}$ Is DEA-efficlent. Otherwise, if $\mathrm{h}^{*} \mathrm{j}_{0}<1$ then the DMU $j_{0}$ is DEA-lnefflelent.

Actually this definition means the following ([5]):

(1) Output Orlentation:A DMU is inefficlent if 1 is possible to augment any output without increasing any input and without decreasing any other output.

(ii) Input orlentation:A DMU is inefficient if it is possible to decrease any input without augmenting any other input

$\checkmark$ and without decreasing any output.

A DMU will be characterized as efficient if, and only if, neither (1) nor (11) obtalns.

For an inefficient DMU, It is very important to find out other DMUs which drive the DMU into inefficlency. [Definition 2]

The efficlent frontler to a DMU $J_{0}$ is the set of DMUs:

$E\left(J_{0}\right)=\left\{j:\left(\sum u^{*}{ }_{r}{ }_{r J}\right) /\left(\sum v^{*}{ }_{1} x_{1 j}\right)=1, j=1, \ldots, n\right)$,

where $u^{*} \underset{r}{r} v^{*}$ are the optimal solutions to [FP(j $\left.\left.]_{0}\right)\right]$.

\section{BENEFIT/COST ANALYSIS BY AHP}

Benef 1 tcost analysls of AHP consists of two processes, namely benefit process and cost process ([6]). We estimate the benefit priorlty and the cost priorlty separately by AHP. Then thelr ratlo gives the relative efficlency of the alternative objects. In this sectlon, first, we consider the b/c analyais in the case of three level perfect hlerarchy structure and then show that general cases can be reduced to the three level case. 


\subsection{Three level perfect graph case}

We will deal with three level hlerarchy structure as deplcted in Fig.1. We call a graph of the structure a perfect hlerarchy Braph if a node in any level is connected to every nodes in the succeeding level by an arc and is not connected direclly to any nodes beyond the succeedlng level.

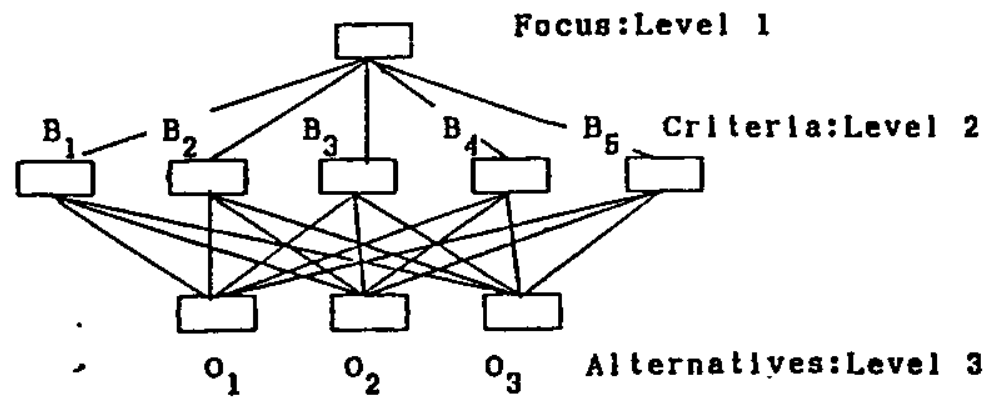

Flgure 1. Three level perfect hlerarchy graph.

We assume that we have $\mathrm{g} k \mathrm{k}$ ds of beneflt crlterla $\left(B_{1}, \ldots B_{8}\right)$ in Level 2 and $n$ kinds of alternative objects $\left(0, \ldots, 0_{n}^{8}\right)$ in Level 3 . Let $y$ be the prlorlty of the obfect $0{ }^{n}$ assoclated with the Eriterla $B_{\text {and }} U_{r}$ be the priority of the crilerion $B_{r}$. Then, the Gverall ${ }^{5}$ benefit of the object $o_{j}$ is given by

$$
\sum_{r=1}^{B} U_{r^{2}} \mathrm{rJ}^{-} \quad(\mathrm{J}=1, \ldots, n)
$$

Here, $y_{r j}$ and $U_{r}$ satisfy

$$
\sum_{j=1}^{n} y_{r j}=1 \quad(r=1, \ldots, 8)
$$

and

$$
\sum_{r=1}^{8} U_{r}=1
$$

Simllarly, we assume that we have a perfect hierarchy cost

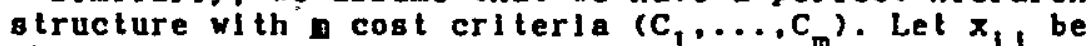
the priority of the object o, with respect to $c_{1}$ and $v_{1}$ be the priority of $C_{1}$. They atiofy

$$
\sum_{j=1}^{n} x_{1 j}=1 \quad(1=1, \ldots, m)
$$

and

$$
\sum_{1=1} v_{1}=1
$$


Then, the overall cost of $o_{j}$ is glven by

$$
\sum_{i=1}^{m} v_{1} x_{1 j} . \quad(J=1, \ldots, n)
$$

The beneflt/cost priorlty of the object of is evaluated by

$$
H_{j}=\left(\Sigma U_{r} y_{y j}\right) /\left(\Sigma, v_{1} x_{1 j}\right) \text {. }
$$

We notlce that in AHP all the elements of $x, y, u$ and $y$ are estimated by the processes of palrulse comparisons and elgenvector welghtings or by some other empirical or theoretical evaluations.

\subsection{General cases}

For a general nulti-level gtructure case, we will reduce it to a three level problem by choosing a bey level between focus and alternatives and by aggregating the levelg between them as deplcted in Fig. 2. If gome arcs bypass the key level (Level 2), we will introduce additlonal nodes in the level Bo that any path connecting the Level 1 node (focus) to a Level 3 node (alternatlves) should meet a node in Level 2.

Also, we vill introduce additlonal dumy arcs with very small $x$ or $y$ values to make the three level structure "perfect". if necessary. It 18 easy to see that we can calculate the $x, y$, $U$ and $v$-values corresponding to the aggregated three level Btructure from the original values.

Thus, general multi-level cases can be reduced to a three level perfect case by selecting a key level dellberately which usually exists in $A H P$.

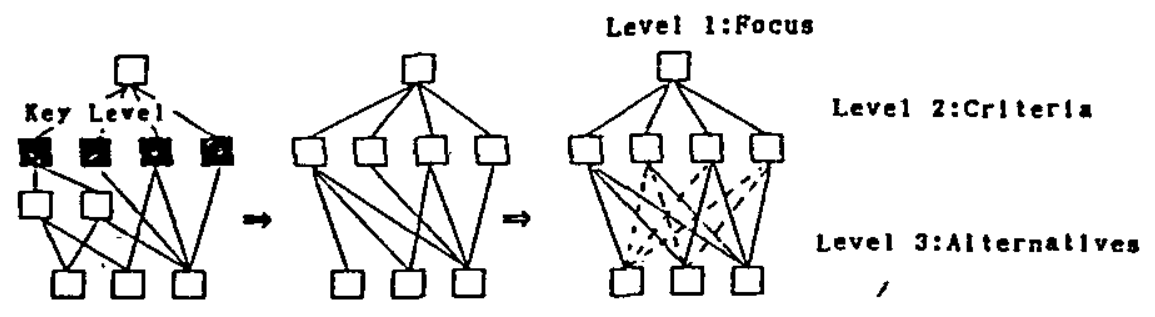

Flgure 2. Reduction of general case to three level perfect graph. 


\section{EFFICIENCIES IN AHP AND DEA}

Discussions in Sections 1 and 2 show the structural siml arlty among b/c analyses by AHP and DEA. Differences exist in the way they estimate $x, y, u, v$, U and V values.

\subsection{Input $x$ and output $y$}

DEA uses avallable numerical data for input $x$ and output $y$, while AHP creates them by the processes of palrwise comparisons and elgenvector welghtings. Originally, DEA alms at evaluating relative efficiencies of DMUs in the environments where numerical or theoretlcally prescribed data exlst. On the other hand, AHP works in the world where only subjectlve or psychological factors are prevailing in making decigiong. Although both methods stem from extremely different motlvations. they exhibit a certain 8 imilarlty in the presence of data i.e. Input $x$ and output $y$ and the ratio scale of efficiency evaluations. They can trade thelr inputg and outputs.

AHP could be benefited by using the same numerical data with DEA. DEA could expand its world by incorporating qualitative factors that AHP has exposed for the first time.

\subsection{Heights}

DEA determines the weights $u$ and $v$ 'by solving the fractlonal programming [FP( $\left.J_{0}\right)$ ] corresponding to the decision making unit DMU $j o$. Hence, the weights differ from one DMU to another. We will call this kind of welghts as varlable welghts. The welghts are determined in such a way that they should be most favorable to the DMU concerned. AHP uses palrwise comparisons and elgenvector weightings in determining the weighs $U$ and $V$ of the key level criteria. The values are common to all alternative objects. He will call this kind of welghts as flxed.

\subsection{Effleiency}

The AHP-efficiency $H_{4}$ of an object $O_{j}$ is given by the farmula (2.7). The DEA-efficiency of a DMU $j_{0}$ is the optimal objective function value to $\left[F P\left(J_{0}\right)\right]$ :

$$
\left.h^{*}\right]_{0}=\left(\Sigma u^{*} r^{y_{j}}\right) /\left(\Sigma v^{*} x_{1 j_{0}}\right)
$$

where $u^{*}$ and $v^{*}$ are the optimal solution to $\left[F P\left(3_{0}\right)\right]$.

For any AHP- $(U, V)$, let

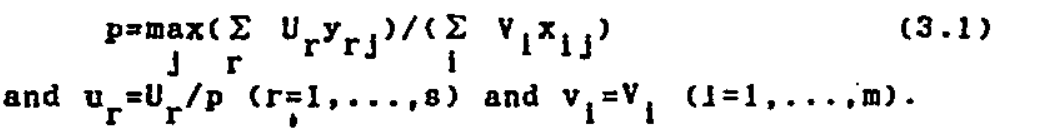


Then, $(u, v)$ is feasible to [FP(J)].

Conversely, for any DEA-feasible solution $(u, v)$, let $T=\Sigma u_{r}$

and $s=\Sigma v_{1}$ and define $U_{r}=U_{r} / T(r=1, \ldots, s)$ and

Then $(U, V)$ is an AHP-feasible priority.

since both transformations are scalings, they have the same priority relations in the b/c analysis.

\subsection{Several propositions}

The above discussions lead us to several propositions. Throughout this sub section we assume $x$ and $y$ to be constant.

\section{[Proposition 1]}

For any AHP welght $(U, V)$, there existg a DMU Jo that has the transformed $(u, v)$ as the optimal solution to $\left[F P\left(J_{0}\right)\right]$. Indeed, $J_{0} 18$ the DNU that gives the maximum value to $q_{3.1}$ ).

\section{[Proposition 2]}

DEA is the most generous one among the multiple criterla methods for evaluating the efficlency of DMUs by ratio scale in the sense that an efflcient DMU under the latter criterla has a corresponding DEA optimal welght $(u, v)$ which makes the DMU be DEA-efficient.

\section{[Proposition 3]}

A DEA-ineficient DMU is also AHP-inefficlent by any weighting of the criteria. Moreover, a DEA-inefflcient DMU is Inefficlent under any flxed welght multiple criterla benefl $\mathrm{t} / \cos \mathrm{t}$ analysis..

\section{CONCLUDING REMARKS}

Both AHP and DEA have turned out to give gtrong impulses to the multiple criterla decision making community, al though thelr origins and motivations are quite different.

In this short report, we polnted out structural simllarlities among them in case of the b/c analygis and suggested their potentlal trades.

In short, AHP could be more objective by incorporaling the DEA-efficlency. AHP can exclude essentlaliy inefflclent objects by usling DEA-inefflclency. Conversely, DEA could be more subjectively orlented by incorporating some features of AHP. For example, by adding such constraints as $u_{1} u_{2}$ or $3 v_{1} \leq v_{2}$ to $\left.\left[F P(]_{0}\right)\right]$. DEA would become more intensive in Judging $^{1}$ the ${ }^{2}$ efflciendy of the DMU concerned.

Although we have concerned malnly with the comparative study on the $b / c$ analyses of AHP and DEA, it should be noted that the usual AHP could be regarded as a special case of the b/c AHP where the cost factor has only one criterion with 
equal welght to each object of alternatives. Hence, the Propositions 1 to 3 remain valld 1 n the latter case. where the corresponding $\left[F P\left(J_{0}\right)\right]$ of DEA reduces to a linear programing.

\section{REFERENCES}

[1]Banker, R.D. "Estimating Most Productive Scale Slze Using Data Envelopment Analysis," European J. Oper. Res., (1984), 36-44.

[2]Banker, R.D. A.Charnes and W.W.Cooperr, "Some Models for EstImating Technlcal and Scale Inefficlencies," Management Sc1.,(1984),1078-1092.

[3]Charnes,A.,W.W.Cooper,B.Golany and L.Selford, "Foundation of Data Envelopment Analys 18 for Pareto-Koopmang Efficient Empirlcal Production Functions," J. Econometrics, (1985),91-107.

[4]Charnes,A. W.W.Cooper and E. Rhodes, "Measuring the Efficlency of Decls ion Making Unlts," European J. of Oper. Res.. (1978), 429-444.

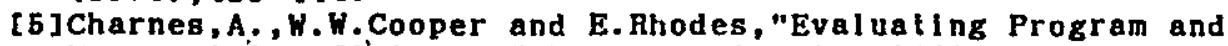
Managerial Efflclency," Management Scl.,(1981),668-697. 1980 . 